\title{
Kewenangan Anak Tertua Dalam Pembagian Harta Waris (Studi Di Desa Bagendang Permai Kecamatan Mentaya Hilir Utara Kabupaten Kotawaringin Timur)
}

\author{
Dedy Irawan \\ Bank BRI Kotawaringin Timur \\ Dedyirawan137@gmail.com
}

\begin{abstract}
The background of the authority Elder Son In Divisonof property inheritance at the village of Bagendang Permai district at MentayaHilir Utara of East Kotawaringin, the basis of the authority of Elder Son In Divison was entrusted to distributed the property inheritance at village BagendangPermai district of MentayaHilir Utara of East Kotawaringin, the implementation of the distribution property inheritance by the oldest child of his/her family at the village of Bagendang Permai of the district Mentaya Hilir Utara of East Kotawaringin. This study used qualitative descriptive method which collected data derived from the words obtained in observation, interviews, and documentation, subjects were 10 family. The results showed that the oldest child has an obligation to distribute the property inheritance owned by parents to each heir is the right to receive. The basicof authority was entrusted by oldest child to distribute of the property inheritance, because the mandater entrusted by their parents elder son In Divison to distribute left to heirs. The impelementation of the distribution of property inheritance by the eldostchild to his/her family at the village of BagendangPermai, the family gathered for deliberation to distribute the properti inheritance owned by their parents were led by Elder Son in the family.
\end{abstract}

Keywords: the authority of elder son, distribution,property inheritance

\section{A. Pendahuluan}

Harta warisan merupakan harta yang diberikan dari orang yang telah meninggal kepada orang-orang terdekatnya seperti keluarga dan kerabatkerabatnya. Pembagian harta waris dalam Islam telah begitu jelas diatur dalam Al Qur an, yaitu pada surat An Nisa ayat 11.

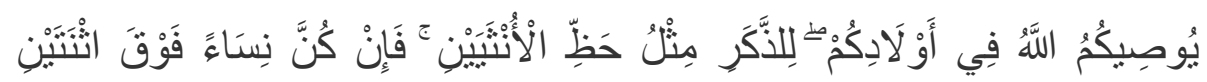

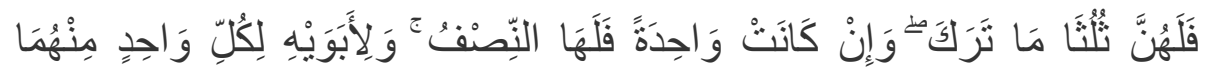

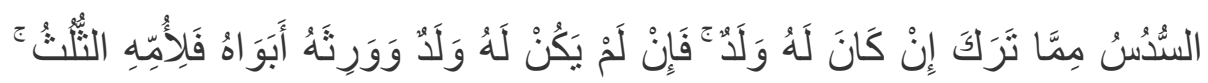

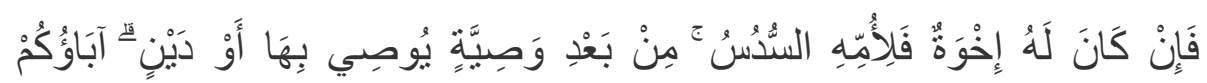

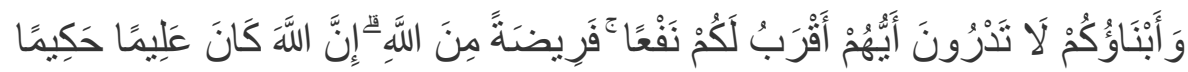


Terjemahan :"Allah mensyari'atkan bagimu tentang (pembagian pusaka untuk) anak-anakmu. yaitu : bahagian seorang anak lelaki sama dengan bagian dua orang anak perempuan dan jika anak itu semuanya perempuan lebih dari dua, Maka bagi mereka dua pertiga dari harta yang ditinggalkan; jika anak perempuan itu seorang saja, Maka ia memperoleh setengah dari harta. dan untuk dua orang ibubapa, bagi masing-masingnya seperenam dari harta yang ditinggalkan, jika yang meninggal itu mempunyai anak; jika orang yang meninggal tidak mempunyai anak dan ia diwarisi oleh ibu-bapanya (saja), Maka ibunya mendapat sepertiga; jika yang meninggal itu mempunyai beberapa saudara, Maka ibunya mendapat seperenam. (Pembagianpembagian tersebut di atas) sesudah dipenuhi wasiat yang ia buat atau (dan) sesudah dibayar hutangnya. (Tentang) orang tuamu dan anakanakmu, kamu tidak mengetahui siapa di antara mereka yang lebih dekat (banyak) manfaatnya bagimu. Ini adalah ketetapan dari Allah. Sesungguhnya Allah Maha mengetahui lagi Maha Bijaksana.”

Ayat tersebut memberikan pemahaman bahwa pembagian harta waris merupakan suatu kewajiban yang harus dilaksanakan oleh ahli waris. Pembagian harta warisan untuk laki-laki mendapatkan 2 bagian dan untuk perempuan mendapatkan 1 bagian sesuai dengan ketentuan yang di syari'atkan oleh Allah. Pembagian harta warisan juga harus melalui kesepakatan di antara keluarga yang ditinggalkan, dan juga harus diselesaikan secara bersama.

Harta waris yang dibagikan sesuai dengan harta yang ditinggalkan setelah pelaksanaan wasiat dan pembayaran hutang. Ketentuan di atas merupakan dasar yang di atur dalam Al Qur'an untuk memberikan pedoman dalam mengarahkan manusia terkait dengan pembagian harta warisan yang bertujuan agar ahli waris yang ditinggalkan oleh orang tuanya tidak terjadi perselisihan dalam membagikan harta waris. Dalam ilmu faraid, harta waris dapat dibagikan jika ada orang yang meninggal dunia mempunyai harta peninggalan bagi ahli waris. Sebelum harta waris itu diberikan kepada ahli waris, ada tiga hal yang terlebih dahulu mesti dikeluarkan, yaitu; Segala biaya yang berkaitan dengan proses pemakaman jenazah, wasiat dari orang yang meninggal, hutang piutang sang mayit. ${ }^{1}$

\footnotetext{
${ }^{1}$ Ahmad Rofiq, Fiqh Mawaris, Jakarta:PT. RajaGrafindo Persada, 2002, h. 46.
} 
Tiga hal di atas telah terpenuhi barulah pembagian harta waris diberikan kepada keluarga dan juga para kerabat yang berhak. Adapun besar kecilnya bagian yang diterima bagi masing-masing ahli waris dapat dijabarkan dalam Al-Qur'an surat an nisa secara gamblang dan dapat kita simpulkan bahwa ada 6 tipe persentase pembagian harta waris, ada pihak yang mendapatkan setengah (1/2), seperempat (1/4), seperdelapan (1/8), dua per tiga (2/3), sepertiga (1/3), dan seperenam (1/6). ${ }^{2}$

Selain ketentuan kewarisan di atas, dalam Kompilasi Hukum Islam Pasal 182 diterangkan bahwa "Para ahli waris dapat bersepakat melakukan perdamaian dalam pembagian harta warisan, setelah masing-masing menyadari bagiannya." Pembagian harta warisan secara perdamaian atau melalui musyawarah boleh dilakukan oleh keluarga ahli waris. Selama pembagian tersebut disepakati secara bersama dan para pihak telah mengetahui bagiannya masing-masing, dimana lakilaki dan perempuan mempunyai hak untuk mendapatkan harta warisan dari ayah atau ibunya serta kerabatnya sesuai dengan yang sudah ditetapkan di dalam Al Qur'an. ${ }^{3}$

Gambaran tentang ketentuan hukum waris di atas berbeda dengan fenomena yang peneliti temui di masyarakat Bagendang Permai bahwa ada kebiasaan masyarakat di desa ini dimana anak tertua merupakan tulang punggung keluarga ketika orang tuanya sudah lanjut usia,dia mempunyai kewajiban menggantikan posisi kedua orang tuanya yang sudah renta sebagai kepala keluarga. Kewajiban anak tertua biasanya lebih memiliki peran penting diantaranya memperhatikan kesehatan makanan, dan melindungi serta mencukupi keperluan lainnya, termasuk sebagai pengayom serta kewajiban melindungi adik-adiknya yang masih kecil.

Ketika orang tuanya semakin lanjut usia, maka anak tertua diamanatkan dalam bentuk wasiat untuk mengelola harta disaat kedua orang tuanya masih hidup, selanjutnya jika kelak kedua orang tuanya meninggal

\footnotetext{
${ }^{2}$ Syahruin Umar, Pembagian Harta Waris http//Pembagian-harta-waris-Islam. html, diakses 15 Januari 2015.

${ }^{3}$ Lihat surat An Nisa Ayat 7.
} 
dunia maka anak tertua ini juga diberikan kewenangan membagikan harta waris kepada saudara-saudaranya.

Sudut pandang Hukum Islam peristiwa wasiat sekaligus amanat sebagaimana yang digambarkan di atas pada dasarnya dibolehkan dalam hukum Islam, hal ini masuk dalam kategori hukum wasiat wajibah. Akan tetapi dalam pelaksanaan pembagian kewarisan menurut observasi Penelitidi desa Bagendang Permai Kecamatan Mentaya Hilir Utara bahwa ada sebagian keluarga yang Peneliti temui dalam membagikan warisan dimana anak tertua mendapatkan hak warisan yang lebih banyak dari saudara yang lainnya, dengan alasan karena pembagian harta warisan tersebut berdasarkan amanat dari orang tuanya.

Modusnya pelaksanaan pembagian harta warisan 100 hari pasca meninggalnya orang tua, anak tertua mengumpulkan saudara-saudaranya untuk musyawarah mufakat dalam membicarakan jumlah harta yang ditinggalkan oleh orang tua mereka untuk selanjutnya dilakukan pembagian hak waris kepada para pihak ahli waris. Praktik pembagian harta warisan secara kekeluargaan tersebut pada umumnya anak tertua mendapatkan bagian yang lebih banyak daripada saudara-saudara yang lainnya dengan alasan yang belum peneliti ketahui secara konkrit, baik dihubungkan dengan kajian hukum waris Islam, hukum waris adat maupun hukum waris perdata. ${ }^{4}$

Berdasarkan latar belakang tersebut, peneliti tertarik untuk meneliti permasalahan tentang Pelaksanaan Pembagian Harta Warisdi Desa Bagendang Permai Kecamatan Mentaya Hilir Utara Kabupaten Kotawaringin Timur,dan diaktualisasikan dalam bentuk karya ilmiah yang berjudul:““ Kewenangan Anak Tertua Dalam Pembagian Harta Waris (Studi diDesa Bagendang Permai Kecamatan Mentaya Hilir Utara Kabupaten Kotawaringin Timur)."

${ }^{4}$ Observasi dan Wawancara Bersama Ahli Waris Ibu Galuh Binti Muhamad di Desa Bagendang Permai, 05 Januari 2015. 


\section{B. Kajian Pustaka}

Untuk memperjelas wawasan penelitian ini, maka penting bagi peneliti untuk mengkaji terlebih dahulu penelitian yang sudah ada sebelumnya. Setelah melakukan beberapa kajian mengenai skripsi tentang kewarisan banyak sekali yang memang sudah melakukan kajian ini. Penelitian-penelitian sebelumnya cukup beragam sehingga peneliti cukup mudah dalam mencari bahan penelitian ini. Adapun penelitian yang sudah dilakukan sebagai berikut:

> Mansur Fahmi STAIN Palangka Raya, Prodi AHS 2002.

Pembagian Harta Orang Tua Kepada Anak Sebelum Meninggal Menurut

Hukum Islam (Studi Kasus di Baamang Hulu Kabupaten Kotawaringin Timur). Penelitian ini bertujuan untuk mengetahui apa yang melatarbelakangi pembagian harta orang tua kepada anaknya sebelum dia meninggal dan tradisi pembagain harta seperti ini masih berlaku sampai sekarang di lokasi penelitian tersebut. ${ }^{5}$

> Murhanadi STAIN Palangka Raya Prodi AHS 2003.

"Pembagian Harta Warisan Secara Kekeluargaan di Desa Jangkang Baru" Penelitian ini bertujuan untuk mengetahui yang melatarbelakangi pembagian harta waris secara kekeluargaan, keterlibatan orang lain dalam pembagian harta warisan, institusi dalam pengambilan keputusan serta waktu pembagian harta warisan tersebut. Penelitian ini dilakukan karena melihat kondisi masyarakat Jangkang Baru yang mayoritas beragama Islam dan masyarakat disana melakukan pembagian harta warisan secara kekeluargaan yang sudah menjadi kebiasaan bagi mereka. Penelitian ini menggunakan pendekatan kualitatif deskriftif dengan subyek 17 orang ahli waris yang melakukan pembagian harta waris secara kekeluargaan. ${ }^{6}$

Indra Setiawan STAIN Palangka Raya Prodi AHS,2014.

${ }^{5}$ Mansur Fahmi, Pembagian Harta Orang Tua Kepada Anak Sebelum Meninggal Menurut Hukum Islam (Studi Kasus di Kelurahan Baamang Hulu Kabupaten Kotawaringin Timur) (skripsi), Palangka Raya STAIN Palangka Raya, 2002.

${ }^{6}$ Murhanadi, "Pembagian Harta Warisan Secara Kekeluargaan di Desa Jangkang Baru”.STAIN Palangka Raya, Tahun 2003. 
"Pengabaian Pembagian Harta Waris di Desa Paduran Mulya Kecamatan Sebangau Kuala Kabupaten Pulang Pisau”. Penelitian ini bertujuan untuk mengetahui latar belakang Pengabaian Pembagian Harta Waris di Desa Paduran Mulya, untuk mengetahui sikap ahli waris ketika harta waris yang ditinggalkan muwaris tidak dibagikan kepada ahli warissertamemberikan solusi agar masyarakat Desa Paduran Mulya Kecamatan Sebangau Kuala Kabupaten Pulang Pisau tidak lagi mengabaikan pembagian harta waris. Penelitian ini menggunakan metode kualitatif deskriptif. $^{7}$

\section{Metode Penelitian}

Penelitian ini menggunakan jenis pendekatan penelitian kualitatif deskriptif. Menurut Nasir pendekatan kualitatif deskriptif adalah suatu metode dalam meneliti sekelompok manusia, suatu objek bahkan suatu sistem persepsi atau kelas peristiwa pada masa sekarang bertujuan untuk menggambarkan secara sistematis, faktual dan akurat mengenai fakta-fakta, sifat-sifat antara fenomena yang diselidiki. ${ }^{8}$

Menurut Moleong pendekatan kualitatif deskriptif adalah menetapkan objek apa adanya sesuai dengan bentuk aslinya, sehingga data yang sesungguhnya dapat diperoleh. Dari dua sudut pandang M. Nasir dan Moleong cukup memberikan kontribusi pemikiran kepada peneliti dalam menghasilkan data yang akurat, baik secara tertulis maupun secara lisan dari respoden dan informan.Sebab pendekatan ini menggambarkan secara apa adanya mengenai Kewenangan Anak Tertua Dalam Pelaksanaan Pembagian Harta Waris di Desa Bagendang PermaiKecamatan Mentaya Hilir Utara Kabupaten Kotawaringin Timur. Adapun objek penelitian ini adalah penyebab terjadinya Kewenangan anak tertua dalampembagian harta waris di Desa Bagendang Permai.

\footnotetext{
${ }^{7}$ Indra Setiawan, "Pengabaian Pembagian Harta Waris di Desa Paduran Mulya Kecamatan Sebangau Kuala Kabupaten Pulang Pisau”, Palangka Raya, 2014.

${ }^{8}$ M.Nasir, Metode Penelitian Hukum, Jakarta: PT Rineka Cipta, 1999, h. 63.
} 
M. Nasir menambahkan bahwa penelitian menggunakan pendekatan kualitatif deskriptif mempunyai beberapa ciri sebagai berikut; Natural Setting yaitu, data dikumpulkan secara langsung dari lingkungan nyata dalam situasi sebagaimana adanya sampel penelitian dan Manusia sebagai instrumen (responden), merupakan alat pengumpul data utama.

\section{Pembahasan}

Dalam Pembahansan pertama ini peneliti beberapa hal mengenai latar belakang kewenangan anak tertua dalam membagikan harta warisan di Desa Bagendang Permai, latar belakang tersebut antara lain sebagai berikut: Sebagai anak tertua mempunyai tanggung jawab dalam membagikan harta warisan kepada saudara-saudara yang lain, kewajiban untuk menjaga harta orang tua serta menjadi panutan bagi saudara-saudara, untuk melaksanakan acara tahlilan maupun haulan serta mengurusi hutang piutang juga menjadi tanggung jawab sebagai anak tertua, menjadi pelindung bagi keluarga yang ditinggalkan, ketika orang tua sudah tua harus selalu diperhatikan kecukupan mereka, merawat mereka, menjaga serta menjadi tulang punggung keluarga, anak tertua lebih tahu mengenai harta peninggalan dari orang tua, sehingga sebagai anak yang paling tua harus bisa menjaga dan membagikan harta yang dimiliki orang tua untuk dibagikan kepada saudara, orang tua memberikan amanah untuk membagikan harta warisan yang ditinggalkannya. Sebagai anak tertua harus bisa menjadi panutan bagi saudara-saudaranya.

Anak tertua harus bisa menjadi panutan untuk saudara yang lainnya. Ketika orang tua mereka masih hidup dan sudah tua renta maka anak tertua harus bisa merawat serta menjaga mereka melebihi dari saudaranya serta menjadi tulang punggung bagi keluarga. Sebagaimana yang diterangkan dalam Al Quran tentang kewajiban untuk berbakti kepada kedua orang tua surat Al Isra ayat 23.

Terjemahan:"Dan Tuhanmu Telah memerintahkan supaya kamu jangan menyembah selain dia dan hendaklah kamu berbuat baik pada ibu bapakmu dengan sebaik-baiknya. jika salah seorang di 
antara keduanya atau kedua-duanya sampai berumur lanjut dalam pemeliharaanmu, Maka sekali-kali janganlah kamu mengatakan kepada keduanya perkataan "ah" dan janganlah kamu membentak mereka dan ucapkanlah kepada mereka perkataan yang mulia"

Dari ayat di atas dapat diambil pemahaman bahwa seorang anak wajib berbuat baik pada ibu bapaknya dengan sebaik-baiknya. Selanjutnya, jika salah seorang di antara kedua orang tua atau kedua-duanya sampai berumur lanjut dalam pemeliharaan anaknya, maka sekali-kali janganlah si anak bersikap kasar kepada keduanya seperti mengatakan keduanya perkataan "ah" dan janganlah kamu membentak mereka atau bahkan memukul, menyakiti fisik maupun perasaan mereka, melaikan bersikap lemah lembut dan sopan santunlah kepada mereka, seperti mengucapkankata yang menyenangkan hati mereka dengan perkataan yang mulia.

Sebagai anak juga diwajibkan untuk mendoakan orang tua yang telah meninggal, maka itu harus selalu dilakukan.Kebiasaan di masyarakat juga apabila orang tua telah meninggal dunia maka harus dilaksanakan tahlilan untuk mendoakan mereka. Membayarkan hutang piutang orang tua semasa hidup juga menjadi tanggung jawab dari anak-anak nya karena jangan sampai apabila telah meninggal dunia terlilit dengan hutang piutang yang akan menyulitkan di akhirat kelak.

Hendaknya ditanamkan ke dalam diri sanubari yang berhutang, karena kenyataan sering membenarkan sabda Nabi di atas. Berapa banyak orang yang berhutang dengan niat dan tekad untuk menunaikannya, sehingga Allah pun memudahkan baginya untuk melunasinya.Sebaliknya, ketika seseorang bertekad pada dirinya, bahwa hutang yang dia peroleh dari seseorang tidak disertai dengan niat yang baik, maka Allah membinasakan hidupnya dengan hutang tersebut. Allah melelahkan badannya dalam mencari, tetapi tidak kunjung dapat. Dan dia letihkan jiwanya karena memikirkan hutang tersebut. Kalau hal itu terjadi di dunia yang fana, bagaimana dengan akhirat yang kekal abadi. 
Anak tertua juga diberikan amanah yang lebih besar dari orang tua yang telah meninggal untuk membagikan harta warisan yang mereka miliki, maka daripada itulah anak tertua mempunyai kewenangan yang lebih besar membagikan harta warisan kepada saudara-saudaranya. Sehingga inilah yang menjadi latar belakang utama anak tertua mempunyai kewenangan untuk membagikan harta warisan kepada saudara-saudaranya.

Analisis yang kedua yaitu dasar kewenangan anak tertua dipercayakan membagikan harta warisan kepada saudara-saudaranya akan penulis uraikan sebagai berikut:

Pembagian harta waris yang dilakukan memang tidak sesuai dengan pembagian yang ada dalam Al Qur'an karena ada yang lebih banyak mendapatkan harta tersebut, terutama anak tertua namun keluarga menerima karena sudah melakukan musyawarah bersama-sama dan itu sudah disepakati.

Sudah menjadi kebiasaan di masyarakat membagikan harta warisan secara kekeluargaan.

Anak tertua mempunyai kewenangan dalam membagikan harta warisan karena sudah diberikan amanah oleh orang tua membagikan harta warisan kepada saudara-saudaranya.

Masyarakat kurang mengetahui dan memahami bagaimana dasar hukum Islam dalam membagikan harta waris serta belum banyak yang belajar ilmu mawaris.

Berdasarkan beberapa point di atas maka yang menjadi dasar anak tertua membagikan harta warisan dikarenakan sudah diberikan kepercayaan oleh orang tua mereka untuk membagikan harta warisan yang ditinggalkan, anak yang diberikan amanah oleh orang tua mereka memang harus menjalankan amanah tersebut khususnya dalam pembagian harta warisan, anak tertua harus bisa menjadi panutan bagi saudara-saudaranya dan menjadi tanggung jawab anak tertua untuk membagikan harta tersebut kepada saudara-saudaranya, fenomena ini telahmenjadi kebiasaan di masyarakat Bagendang Permai dalam membagikan harta warisan itu secara kekeluargaan 
walapun mereka belum banyak yang mengetahui bagaimana cara membagikan harta warisan yang sesuai pembagiannya di dalam Al Qur'an serta siapa saja yang berhak mendapatkan harta tersebut.

Berdasarkan peristiwa di atas jika dikaji dalam ranah Ushul Fiqh dimana kebiasaan tersebut di istilahkan dengan ' $U r f$. Sesuatu yang menjadi tradisi secara turun temurun oleh masyarakat serta menjadimerupakan kebiasaan di kalangan mereka baik berupa perkataan maupun perbuatan. Sebagian ulama ushul fiqh, 'urf disebut adat (adat kebiasaan).Sekalipun dalam pengertian istilah tidak ada perbedaan antara 'urf dengan adat (adat kebiasaan). Sekalipun dalam pengertian istilah hampir tidak ada perbedaan pengertian antara 'urf dengan adat, namun dalam pemahaman biasa diartikan bahwa pengertian 'urf lebih umum dibanding dengan pengertian adat, karena adat disamping telah dikenal oleh masyarakat, juga telah biasa dikerjakan di kalangan mereka, seakan-akan telah merupakan hukum tertulis, sehingga ada sanksi-sanksi terhadap orang yang melanggarnya. ${ }^{9}$

Sebagaimana yang tertuang dalam kaidah ushul fiqh terkait dengan masalah adat istiadat dinyatakan sebagai berikut:

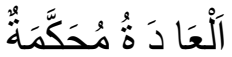

Artinya : "Adat kebiasaan dapat di tetapkan sebagai hukum."

Dari kaidah di atas memberikan pemahaman bahwa adat istiadat dapat dijadikan sebagai hukum di dalam masyarakat, jika hal itu dipandang sebagai tradisi yang baik secara sosial. Atas dasar itulah adat kebiasaan, adat kebiasaan yang berlaku di masyarakat Islam serta tidak melanggar dengan ketentuan syari'at dapat di tetapkan sebagai sumber hukum yang berlaku.Sedangkan adat yang menyimpang dari ketentuan syari'at, walaupan banyak di kerjakan orang tetapi tidak dapat di jadikan sumber hukum.

Allah SWT telah mensyariatkan kepada manusia untuk membagikan harta waris kepada ahli waris karena ahli waris memiliki hak atas harta yang

${ }^{9}$ Abd. Rahman Dahlan, Ushul Fiqh, Jakarta: Amzah, 2011, h. 212. 
ditinggalkan oleh muwaris, dan Allah SWT telah menjelaskan dan merinci secara detail mengenai bagian-bagian yang didapatkan ahli waris dan dengan hukum yang berkaitan dengan hukum kewarisan tanpa mengabaikan hak seorang pun. Pembagian masing-masing ahli waris baik itu laki-laki maupun perempuan telah ada ketentuannya dalam Al-Quran.Sebagaimana Firman Allah dalam Al Qur'an surah An-Nisa ayat 11.

Terjemhan:“Allah mensyari'atkan bagimu tentang (pembagian pusaka untuk) anak-anakmu. Yaitu : Bagian seorang anak lelaki sama dengan bagian dua orang anak perempuan dan jika anak itu semuanya perempuan lebih dari dua, maka bagi mereka dua pertiga dari harta yang ditinggalkan; jika anak perempuan itu seorang saja, maka ia memperoleh separo harta. dan untuk dua orang ibu-bapa, bagi masing-masingnya seperenam dari harta yang ditinggalkan, jika yang meninggal itu mempunyai anak; jika orang yang meninggal tidak mempunyai anak dan ia diwarisi oleh ibubapanya (saja), maka ibunya mendapat sepertiga; jika yang meninggal itu mempunyai beberapa saudara, maka ibunya mendapat seperenam. (Pembagian-pembagian tersebut di atas) sesudah dipenuhi wasiat yang ia buat atau (dan) sesudah dibayar hutangnya. (Tentang) orang tuamu dan anak-anakmu, kamu tidak mengetahui siapa di antara mereka yang lebih dekat (banyak) manfaatnya bagimu.ini adalah ketetapan dari Allah. Sesungguhnya Allah Maha mengetahui lagi Maha Bijaksana."

Ayat di atas menerangkan tentang pembagian harta warisan kepada ahli waris yang berhak menerimanya. Pembagian harta warisan harus sesuai dengan petunjuk yang ada dalam Al Qur'an. Bagian seorang anak lelaki sama dengan bagian dua orang anak perempuan dan jika anak itu semuanya perempuan lebih dari dua, maka bagi mereka dua pertiga dari harta yang ditinggalkan; jika anak perempuan itu seorang saja, maka ia memperoleh separo harta. dan untuk dua orang ibu-bapa, bagi masing-masingnya seperenam dari harta yang ditinggalkan, jika yang meninggal itu mempunyai anak; jika orang yang meninggal tidak mempunyai anak dan ia diwarisi oleh ibu-bapanya (saja), maka ibunya mendapat sepertiga; jika yang meninggal itu mempunyai beberapa saudara, maka ibunya mendapat seperenam. (Pembagian-pembagian tersebut di atas) sesudah dipenuhi wasiat yang ia buat atau (dan) sesudah dibayar hutangnya. 
Hasil wawancara yang dilakukan oleh peneliti dilapangan mengenai cara pelaksanaan pembagian harta warisan maka beberapa hal didapatkan peneliti sebagai berikut:

$>$ Setelah meninggalnya mayit ahli waris mengabarkan kepada seluruh keluarga bahwa orangtua telah meninggal dunia lalu keluarga berkumpul bersama untuk mengurus jenazah agar diurus pemakamannya mulai dari mempersiapkan keperluan pemandian, mengkafani, menyolatkan, serta menguburkan.

$>$ Membayarkan hutang piutang orang tua selama masih hidup agar tidak menjadi penghambat ketika di akhirat kelak.

$>$ Setelah itu dilakukan pengajian untuk mendoakan orang tua yang meninggal atau disebut tahlilan selama beberapa malam dari malam ke 1 sampai malam ke 3, lalu di malam ke 7, malam ke 25 lalu hari 40 kemudian malam ke 100 atau menyeratus.

$>$ Keluarga berkumpul serta bermusyawarah bersama-sama untuk membagikan harta warisan dari orang tua yang meninggal dunia dipimpin oleh anak tertua di keluarga tersebut.

Pembayaran hutang piutang juga harus dilakukan oleh pihak keluarga agar ketika orang tua meninggal di akhirat kelak tidak menjadi penghambat untuk memasuki surga Allah sebagaimana firmannya dalam QS An Nisa ayat 12 sebagai berikut:

Terjemhan: "Maka mereka bersekutu dalam yang sepertiga itu,sesudah dipenuhi wasiat yang dibuat olehnya atau sesudah dibayar hutangnyadengan tidak memberi mudharat (kepada ahli waris)."

Ayat di atas menerangkan mengenai pembayaran hutang piutang apabila orang yang telah meninggal dunia harus dibayarkan hutang piutangnya agar ahli waris bisa membayarkan hutang piutang tersebut dan tidak menimbulkan mudharat dikemudian hari.Setelah itu keluarga berkumpul bersama untuk membagikan harta warisan yang dipimpin oleh anak tertua di dalam keluarga tersebut karena anak tertua mempunyai kewenangan untuk membagikan harta warisan kepada saudara-saudaranya. 
Dalam Kompilasi Hukum Islam Pasal 182 diterangkan bahwa "Para ahli waris dapat bersepakat melakukan perdamaian dalam pembagian harta warisan, setelah masing-masing menyadari bagiannya." Pembagian harta warisan secara perdamaian atau melalui musyawarah boleh dilakukan oleh keluarga ahli waris. Selama pembagian tersebut disepakati secara bersama dan para pihak telah mengetahui bagiannya masing-masing, di mana laki-laki dan perempuan mempunyai hak untuk mendapatkan harta warisan dari ayah atau ibunya serta kerabatnya sesuai dengan yang sudah ditetapkan di dalam Al Quran. ${ }^{10}$

Pelaksanaan pembagian harta warisan di Desa Bagendang Permai berdasarkan sistem kekerabatan bilateral yaitu tidak membedakan antara anak laki-laki dan perempuan untuk mereima harta warisan dari orang tua.

\section{Kesimpulan}

Berdasarkan dari hasil penelitian yang peneliti lakukan, maka dapat diambil beberapa kesimpulan sebagai berikut; Latar belakang kewenangan anak tertua dalam pembagian harta waris di Desa Bagendang Permai Kecamatan Mentaya Hilir Utara Kabupaten Kotawaringin Timur yaitu dikarenakan anak tertua diberikan tanggung jawab yang lebih banyak daripada saudara-saudaranya ketika orang tua masih hidup dan setelah meninggal dunia. Anak tertua baik laki-laki maupun perempuan diberikan kewenangan untuk membagikan harta warisan kepada saudara-saudaranya. Dasar kewenangan anak tertua yang dipercayakan membagikan harta warisan di Desa Bagendang Permai adalah amanat yangtelah diberikan atau kepercayaan yang oleh kuitan atau amanat uma abah kepada anak tertua untuk membagikan harta warisan yang ditinggalkan kepada ahli waris, anak yang diberikan amanah oleh orang tua mereka memang harus menjalankan amanah tersebut khususnya dalam pembagian harta warisan, anak tertua harus

${ }^{10}$ Himpunan Peraturan Perundang-Undangan, Undang-Undang Peradilan Agama Dan Kompilasi Hukum Islam (KHI), Yogyakarta: Graha Pustaka, 2007. 
bisa menjadi panutan bagi saudara-saudaranya dan menjadi tanggung jawab anak tertua.

\section{Daftar Pustaka}

Aspihani, "Penyalahgunaan Harta Warisan Menjadi Modal Usaha", STAIN Palangka Raya, 2003.

Fahmi, Mansur, Pembagian Harta Orang Tua Kepada Anak Sebelum Meninggal Menurut Hukum Islam (Studi Kasus di Kelurahan Baamang Hulu Kabupaten Kotawaringin Timur) (skripsi), Palangka Raya STAIN Palangka Raya, 2002.

Hamidah, "Studi Banding Pembagian Kewarisan Menurut Hukum Islam, Kitab Undang-Undang Hukum Perdata (BW) dan Hukum Adat Banjar”, STAIN Palangka Raya, 2003.

Himpunan Peraturan Perundang-Undangan, Undang-Undang Peradilan Agama Dan Kompilasi Hukum Islam (KHI), Yogyakarta: Graha Pustaka, 2007.

Indra Setiawan, "Pengabaian Pembagian Harta Waris di Desa Paduran Mulya Kecamatan Sebangau Kuala Kabupaten Pulang Pisau”, Palangka Raya, 2014.

Murhanadi , "Pembagian Harta Warisan Secara Kekeluargaan di Desa Jangkang Baru”.STAIN Palangka Raya, Tahun 2003.

Nasir, M., Metode Penelitian Hukum, Jakarta: PT Rineka Cipta, 1999.

Rofiq, Ahmad, Fiqh Mawaris, Cet 3 Jakarta:PT. RajaGrafindo persada, 1998.

, Hukum Islam di Indonesia, Jakarta: PT RajaGrafindoPersada, Cet. Ke-4, 2000. 